E3S Web of Conferences 1, 31002 (2013)

DOI: $10.1051 / \mathrm{e} 3$ sconf/20130131002

(C) Owned by the authors, published by EDP Sciences, 2013

\title{
Bacterial strains resistant to inorganic and organic forms of mercury isolated from polluted sediments of the Orbetello Lagoon, Italy, and their possible use in bioremediation processes
}

\author{
M. Pepi ${ }^{1}$, S. Focardi ${ }^{2}$, A. Tarabelli ${ }^{1}$, M. Volterrani ${ }^{1}$ and S. E. Focardi ${ }^{1}$ \\ ${ }^{1}$ Department of Environmental Sciences, University of Siena, Via P. A. Mattioli, 4; 53100, Siena, ITALY, \\ milva.pepi@unisi.it \\ ${ }^{2}$ Department of Chemistry, University of Siena, Via A. Moro, 2; 53100, Siena, ITALY, silvia.focardi@unisi.it
}

\begin{abstract}
Bacteria are able to adapt to heavy metals in contaminated environments, by developing specific mechanisms of resistance. A mercury ( $\mathrm{Hg}$ )-resistant bacterial community was isolated from polluted sediments of the Orbetello Lagoon, Italy. The members of the Hg-resistant bacterial community showed high levels of resistance both to the inorganic and to the organic forms of Hg. 16S rRNA gene sequencing showed the presence of different genera, and a bacterial strain resistant to $\mathrm{Hg}$ belonging to the genus Luteimonas was evidenced for the first time. The merA gene coding for mercury-reductase conferring resistance to inorganic $\mathrm{Hg}$, and the $\operatorname{merB}$ gene coding for mercury-lyase enzymes, for resistance to the organic forms of $\mathrm{Hg}$, were detected in the tested bacterial strains. The community showed the presence of bacteria belonging to the genera Pseudomonas and Psychrobacter that highlighted the capability to reduce $\mathrm{Hg}^{2+}$ to the volatile form of $\mathrm{Hg}^{0}$. Experiments carried out with immobilized cells of the Hg-resistant strains removed $96 \%$ of $\mathrm{Hg}$ in sediments leachates in a bioremediation laboratory scale pilot plant. A methylating activity of the sulphate-reducing bacteria of the same polluted sediments was moreover evidenced. These results evidenced the presence of microbial communities highly adapted to the presence of $\mathrm{Hg}$ into the sediments of the lagoon. The use of the isolated autochthonous bacterial strains for bioremediation of the native sediments contaminated by $\mathrm{Hg}$ is suggested.
\end{abstract}

Key words: Mercury, bacteria, bacterial resistance, sediments, bioremediation.

\section{Introduction}

Microorganisms are ubiquitous and able to adapt to extreme environments. Among microorganisms, bacteria show different mechanisms of resistance to heavy metals. Interactions of bacteria with heavy metals could change the valence states of the latter, thus modifying their fate in the environment. Some of the interactions bacteria-heavy metals could represent useful processes for toxic elements removal from the environment.

The biogeochemical cycle of mercury $(\mathrm{Hg})$ is well known. $\mathrm{Hg}$ in its ionic form can possibly produce the most toxic form of this metal: methyl mercury (Me-Hg). This organic form of $\mathrm{Hg}$ originates from the methylating activity of sulphate-reducing bacteria and is able to be bioaccumulated and biomagnified in the trophic chain (Barkay et al., 2003).

Bacteria have evolved mechanisms of resistance to deal with high levels of different forms of $\mathrm{Hg}$ in the environment, in virtue of the presence of genes mer $A$ and mer $B$. Bacteria achieve detoxification of $\mathrm{Hg}$ by reduction of $\mathrm{Hg}^{2+}$ to $\mathrm{Hg}^{0}$ and diffusional loss of $\mathrm{Hg}^{0}$ from the cell (Barkay et al., 2003).

$\mathrm{Hg}$ contamination of lagoon sediments is a well-known problem and the relative biogeochemical cycle has been characterized in various places (Han et al., 2007). Sediments of the Orbetello Lagoon, show mercury contamination due to geologic characteristics and to the nearby Monte Amiata mercury mines.

A study on Hg-resistant bacteria was undertaken in order to characterize bacterial strains able to cope with mercury in sediments of the Orbetello Lagoon, and to assess their possible use in bioremediation of this contaminated site.

\section{Materials and Methods}

Orbetello Lagoon, on the Tyrrhenian coast of central Italy 
$\left(42^{\circ} 26^{\prime} 34^{\prime \prime} \mathrm{N}, 11^{\circ} 13^{\prime} 29^{\prime \prime} \mathrm{E}\right)$, covers an area of about 2,300 ha with a water depth of about 1 metre. Superficial sediment sampling was carried out using a grab sampler. Sterile portions for microbiological analyses were maintained at $4^{\circ} \mathrm{C}$ in the dark until arrival at the laboratory. Enrichment cultures arranged in Nelson's medium $(\mathrm{NeM})$, in the presence of $10 \mu \mathrm{g} \mathrm{ml}^{-1}$ of mercury chloride $\left(\mathrm{HgCl}_{2}\right)$ allow isolation of $\mathrm{Hg}$-resistant bacterial strains. Isolates were stored at $-80^{\circ} \mathrm{C}$ in $30 \%$ sterile glycerol. For $16 \mathrm{~S}$ rDNA sequencing of isolated bacterial strains, a single colony was suspended in $50 \mu \mathrm{l}$ double-distilled water and treated for $5 \mathrm{~min}$ at $100^{\circ} \mathrm{C}$. Amplification of the 16S rRNA gene was accomplished. Sequencing was carried out at the Bact 16S biomolecular research service (CRIBI Biotechnology Centre, University of Padua, Italy). Resistance to inorganic mercury added as $\mathrm{HgCl}_{2}$ and to organic mercury added as $\mathrm{CH}_{3} \mathrm{HgCl}$ in isolated bacterial strains was assessed by MIC tests. The presence of mer $A$ and $\operatorname{mer} B$ genes in the isolates was investigated. Three of the isolated Hg-resistant bacterial strains were tested for their capacity to volatilize inorganic mercury $\left(\mathrm{HgCl}_{2}\right)$ and organic mercury $\left(\mathrm{CH}_{3} \mathrm{HgCl}\right)$. The presence of methylating activity in anaerobic cultures of sulphate-reducing bacteria originated from the same polluted sediments was moreover investigated.

Cells of the mercury-resistant bacterial strains ORHg1, ORHg4 and ORHg5 adhering to pumice particles were tested for their capacity to remove mercury from liquid solutions consisting of Nelson's medium with $10 \mu \mathrm{g} \mathrm{ml}^{-1}$ of $\mathrm{Hg}^{2+}$ (added as $\mathrm{HgCl}_{2}$ ) or from leachate solutions containing mercury obtained from sediments treated with acidic solutions.

\section{Results and Discussion}

A microbial community Hg-resistant was isolated from sediments of the Orbetello Lagoon, Italy, where the presence of $\mathrm{Hg}$ contamination is well known. 16S rRNA gene sequences assigned the isolates to the genera Bacillus, Pseudomonas, Psychrobacter, Halomonas, Luteimonas and Micrococccus. Resistance to $\mathrm{Hg}$ in a bacterial strain belonging to the genus Luteimonas was evidenced for the first time. Levels of resistance to inorganic mercury, added as $\mathrm{HgCl}_{2}$ ranged from $0.01 \mathrm{mM}$ to $0.3 \mathrm{mM}$. Those of resistance to organic mercury, added as $\mathrm{CH}_{3} \mathrm{HgCl}$ showed a range included from $0.0005 \mathrm{mM}$ to $0.01 \mathrm{mM}$. Strain Psychrobacter sp. ORHg1 showed resistance to $\mathrm{HgCl}_{2}$ at a value of $0.1 \mathrm{mM}$, and strains Pseudomonas spp. ORHg4 and ORHg5 showed levels of resistance of $0.075 \mathrm{mM}$ in the presence of the same inorganic form of $\mathrm{Hg}$. With respect to the organic form of mercury, ORHg1 showed higher levels of resistance to $\mathrm{CH}_{3} \mathrm{HgCl}(0.005 \mathrm{mM})$, and strains ORHg4 and ORHg5 were resistant to $0.0025 \mathrm{mM} \mathrm{CH}_{3} \mathrm{HgCl}$. Levels of resistance of the isolates to inorganic and organic mercury revealed by MIC values were substantially similar to values in the literature for heterotrophic aerobic bacteria (Baldi et al., 1993). For all three tested bacterial strains, Psychrobacter sp. ORHg1, Pseudomonas sp. ORHg4 and Pseudomonas sp. ORHg5, the capacity to volatilize ionic mercury added as $\mathrm{HgCl}_{2}$ was greatest within five-ten minutes of the contact between the induced bacterial cells and $\mathrm{Hg}^{2+}$ (Fig. 1). Levels of mercury removal detected in this work were similar to those previously reported for heterotrophic Hg-resistant bacterial strains (Capolino et al., 1997). Genes merA and mer $B$ were evidenced in bacterial strains of the Hg-resistant community isolated from sediments of the Orbetello Lagoon. Microbial diversity of a bacterial consortium for mercury detoxification could provide a reservoir of strains with complementary ecological niches, resulting in a better efficiency in eventual bioremediation processes (Wagner-Döbler, 2003). Methylating activities of $\mathrm{Hg}^{2+}$ by anaerobic suphate-reducing bacteria, from the same polluted sediments, were evidenced.

A laboratory scale bioreactor with fixed beds with isolates immobilized as biofilms showed good efficiency $(96 \%)$ in mercury removal from sediments leachate solutions. An extended description of the pilot plant was reported (Pepi et al., 2011).

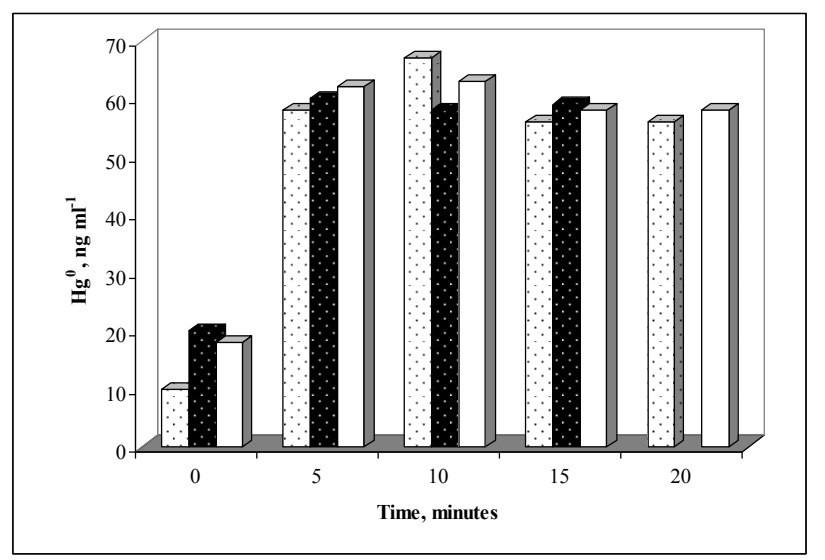

Fig. 1. Volatilization of $\mathrm{Hg}^{2+}$ to $\mathrm{Hg}^{0}$ by the $\mathrm{Hg}$-resistant

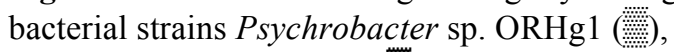

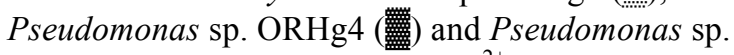
ORHg5, ( $\square$ ) in the presence of $\mathrm{Hg}^{2+}$ added to the dense bacterial culture as $\mathrm{HgCl}_{2}$.

\section{Conclusion}

The isolated Hg-resistant bacterial strains could be used in bioremediation applications to remove mercury from sediments. This application could be especially important in sites where mercury contamination reaches high values, with the presence of methylmercury, where it would decrease the mercury content in portions of removed sediments before their safe storage, thereby decreasing managements costs.

The isolated $\mathrm{Hg}$-resistant bacterial community represents a reservoir of bacterial strains to be maintained and characterized for applications of bioremediation.

Autochthonous adapted bacterial strains of contaminated sites could represent an opportunity for environmental friendly processes and for eventual 
processes able to remove heavy metals, thus avoiding contacts with living organisms.

\section{Acknowledgements}

The authors thank for the provided financial supports the Monte dei Paschi di Siena and the Higher Institute for Environmental Protection and Research (ISPRA).

\section{References}

Baldi F, Pepi M, Filippelli M. Methylmercury resistance in Desulfovibrio desulfuricans strains in relation to methylmercury degradation. Appl Environ Microbiol 1993; 59:2479-2485.

Barkay T, Miller SM, Summers AO. Bacterial mercury resistance: from atoms to ecosystems. FEMS Microbiol Rev 2003; 27:355-384.

Capolino E, Tredici M, Pepi M, Baldi F. Tolerance to mercury chloride in Scenedesmus strains. Biometals 1997; 10:85-94.
Grassi S, Netti R. Sea water intrusion and mercury pollution of some coastal aquifers in the province of Grosseto (Southern Tuscany - Italy). J Hydrol 2000; 237:198-211.

Han S, Obraztsova A, Pretto P, Choe K-Y, Gieskes J, Deheyn DD, Tebo BM. Biogeochemical factors affecting mercury methylation in sediments of the Venice lagoon, Italy. Environ Toxicol Chem 2007; 26:655-663.

Pepi M, Gaggi C, Bernardini E, Focardi S, Lobianco A, Ruta M, Nicolardi V, Volterrani M, Gasperini S, Trinchera G, Renzi P, Gabellini M, Focardi SE. Mercury-resistant bacterial strains Pseudomonas and Psychrobacter spp. isolated from sediments of Orbetello Lagoon (Italy) and their possible use in bioremediation processes. Int Biodeter Biodegr 2011; 65:85-91

Wagner-Döbler I. Pilot plant for bioremediation of mercury-containing industrial wastewater. Appl Microbiol Biotechnol 2003; 62:124-133. 